International Journal of Agriculture and Environmental Research

ISSN: 2455-6939

Volume: 06, Issue: 03 "May-June 2020"

\title{
OPTIMIZATION OF VACUUM OVEN DRYER FOR APPLE DRYING
}

\author{
${ }^{1}$ NADEEM AHMED, ${ }^{2}$ BURHAN JEELANI \\ ${ }^{1,2}$ College of Agricultural Engineering and Technology, \\ SKUAST -K, Shalimar campus, Srinagar, 190025
}

DOI: 10.46609/IJAER.2020.v06i03.005 URL: https://doi.org/10.46609/IJAER.2020.v06i03.005

\begin{abstract}
Apple slices were dried in a vacuum oven at temperature $90^{\circ} \mathrm{C}$ and $100^{\circ} \mathrm{C}$ respectively. Samples dried had thickness $4 \mathrm{~mm}, 5 \mathrm{~mm}$ and $6 \mathrm{~mm}$ of two varieties of apples viz. red delicious and golden delicious. Drying shrinkage was measured by means of a measuring cylinder with the help of distilled water. Color assessment was conducted based on the results obtained with the use of a reflective colorimeter. The kinetics of apple slices drying with vacuum oven dryer was described using exponential functions. The vacuum oven method considerably shortened total time of dying and decreased drying shrinkage. Apple slices dried with vacuum oven method demonstrated better by rehydrating properties manifested by absorption capacity, dry matter holding capacity and rehydration ability. Vacuum method drying, results in the browning of apples slices was found more in red delicious as compared to golden delicious.
\end{abstract}

Keywords: Vacuum drying, Apple slices, Red delicious, Golden delicious.

\section{INTRODUCTION}

The horticulture occupies a very significant position in the agricultural sector of Indian economy. The various fruits grow in India and are exported to different countries in the world. However, apple production is most prominent one in India. In India apples are grown as a commercial crop in the hilly areas. The apple fruit grows especially in the state of J\&K. Apple production is one of the important sources of economy in $\mathrm{J} \& \mathrm{~K}$. Apple cultivation in $\mathrm{J} \& \mathrm{~K}$ is fast expanding because apple has a comparative advantage over the other crops that can be grown in hilly regions. Kashmir has a rich heritage of fruit cultivation. Walter. R. Lawrence, who in his book "The Valley of Kashmir" (1895) revealed that "Kashmir is the country of fruits and perhaps no country has greater facilities for horticulture, as the indigenous apples, pear, vine, mulberry, walnut, hazel, cherry, peach, apricot, strawberry, raspberry can be obtained without any difficulty in most parts of the valley of Kashmir. Apple industry is one of the important sources of economy and its Apple cultivation in the state is fast expanding because apple has a comparative advantage over the other crops that can be grown in hilly regions. 
International Journal of Agriculture and Environmental Research

ISSN: 2455-6939

Volume: 06, Issue: 03 "May-June 2020"

$\mathrm{J} \& \mathrm{~K}$ is major apple producing state accounting for $67.7 \%$ of the total apple production in the country and the production per hectare is 10.0 metric tons, which is higher than the national average. The production of apple in state has increased from 1093335 metric tons in 2004-05 to 1367805 metric tons in 2009-10. The production per hectare or average yield in Kashmir valley was 10.94 metric tons in 2004-05; it increases to 11.2 metric tons in 2009-10. The state of Jammu and Kashmir is the largest apple producing state in India. As per the horticulture reports of 2008-09 $\mathrm{J}$ and $\mathrm{K}$ produces about $71 \%$ of national production. As per the department of horticulture, J\&K, the annual production of apple in the year 2018-19 is 18 lakh metric tonnes. It has taken decades to develop Jammu and Kashmir as major apple producing state in India. The cultivation of apple is done in all districts of Kashmir valley. Major contributors to the apple production are Baramulla, Shopian, Pulwama, Budgam, Anantnag, Kulgam etc. Apples are consumed and cultivated across the world and some part of production are consumed fresh and small part of production is processed in juices, jellies, slices and other jam items.

Drying is a mass transfer process consisting of the removal of water or another solvent by evaporation from a solid, semi-solid or liquid. This process is often used as a final production step before selling or packaging products. To be considered "dried", the final product must be solid, in the form of a continuous sheet (e.g., paper), long pieces (e.g., wood), particles (e.g., cereal grains or corn flakes) or powder (e.g., sand, salt, washing powder, milk powder). A source of heat and an agent to remove the vapor produced by the process are often involved. In bio products like food, grains, and pharmaceuticals like vaccines, the solvent to be removed is almost invariably water. Desiccation may be synonymous with drying or considered an extreme form of drying. In some products having a relatively high initial moisture content, an initial linear reduction of the average product moisture content as a function of time may be observed for a limited time, often known as a "constant drying rate period". Usually, in this period, it is surface moisture outside individual particles that is being removed. The drying rate during this period is mostly dependent on the rate of heat transfer to the material being dried. Therefore, the maximum achievable drying rate is considered to be heat-transfer limited. If drying is continued, the slope of the curve, the drying rate, becomes less steep (falling rate period) and eventually tends to nearly horizontal at very long times. The product moisture content is then constant at the "equilibrium moisture content", where it is, in practice, in equilibrium with the dehydrating medium. In the falling-rate period, water migration from the product interior to the surface is mostly by molecular diffusion, i,e. the water flux is proportional to the moisture content gradient. This means that water moves from zones with higher moisture content to zones with lower values, a phenomenon explained by the second law of thermodynamics. If water removal is considerable, the products usually undergo shrinkage and deformation, except in a well-designed freeze-drying process. The drying rate in the falling-rate period is controlled by the rate of removal of moisture or solvent from the interior of the solid being dried and is referred to as 
being "mass-transfer limited". This is widely noticed in hygroscopic products such as fruits and vegetables, where drying occurs in the falling rate period with the constant drying rate period said to be negligible.

Vacuum drying is the mass transfer operation in which the moisture present in a substance, usually a wet solid, is removed by means of creating a vacuum. In chemical processing industries like food processing, pharmacology, agriculture, and textiles, drying is an essential unit operation to remove moisture. Vacuum drying is generally used for the drying of substances which are hygroscopic and heat sensitive, and is based on the principle of creating a vacuum to decrease the chamber pressure below the vapor pressure of the water, causing it to boil. With the help of vacuum pumps, the pressure is reduced around the substance to be dried. This decreases the boiling point of water inside that product and thereby increases the rate of evaporation significantly.

The result is a significantly increased drying rate of the product. The pressure maintained in vacuum drying is generally $0.03-0.06$ atm and the boiling point of water is $25-30^{\circ} \mathrm{C}$. The vacuum drying process is a batch operation performed at reduced pressures and lower relative humidity compared to ambient pressure, enabling faster drying.

\section{OBJECTIVES}

The overall objective of the study is to optimize the drying process for apple slices for given species by comparing various quality parameters.

The specific objectives are;

- To study the drying characteristics of apple slices at different air temperature and slice thickness

- To study the sensory characteristics of the dried product.

- To optimize the dying parameters and fit suitable mathematical model.

\section{SCOPE AND LIMITATIONS}

The scope of drying in Kashmir in very abundant. This is due the reason that apple production in Kashmir is nearly 13 lakh metric tonnes, which seems to be fairly significant. Hence apple processing holds tremendous scope. With reference to the given study, dried apples can be used as secondary food products.

Furthermore, the shelf life of apples can be extended up to 1 year if apples are stored in cold storage post drying. Total drying time can be reduced as drying rates accelerate in low pressure conditions. 
International Journal of Agriculture and Environmental Research

ISSN: 2455-6939

Volume: 06, Issue: 03 "May-June 2020"

There are no limitations in the study except the fact that the vacuum oven dryer used in this study is not equipped with steam jacket which helps in automatic draining of steam/vapour, due to which vapor saturation took place after every 10-15 minutes of drying hence decreasing drying rates and unnecessary extending drying time.

\section{REVIEW OF LITERATURE}

Apples belong to popular fruits grown in Kashmir. Apples exhibit relatively high metabolic activity compared to other plant-derived foods (Ahmet et al.2005) Due to high content of water, they require storage in strictly specified conditions or drying aimed at reducing water activity to a level assuring microbiological safety (Mathlouthi, 2001). The drying objective is to reduce the water to a certain level to minimize microbial waste (Apinar and Bier 2005].

The most common method of biological materials dehydration is convective drying. Its fault is high energy consumption and low effectiveness of drying. Van Arsdel et al. (1973) indicated that hot-air drying can cause heat damage and adversely affect flavor, color, size, texture and nutritional value of the products.

Case-hardening is a common defect particularly found in dried fruits due to rapid drying. As drying progresses, the rate of water evaporation is faster than the rate of water diffusion to the product surface. Therefore, the outer skin becomes dry and acts as a water barrier, causing a wet interior. Furthermore, loss of volatile compounds inevitably occurs during drying. Since the products are exposed to high temperature for a long period, these volatile compounds are vaporized and lost with water vapour. This causes a significant loss of characteristic flavor in dried products. High temperature and long drying time also degrade the product's original colour.

Therefore, alternative, energy efficient drying methods are necessary for the food industry in order to manufacture products of high quality. [Yongsawatdigul et al. 1995].

Vacuum drying is an alternative method for drying fruits. The vacuum allows water to vaporize at a lower temperature than at atmospheric conditions. Therefore, fruits can be dried without exposure to high temperature. Moreover, the absence of air during dehydration diminishes oxidation reactions. Because of these advantages, the color, texture and flavour of dried products are improved.

Ismail (1989) patented a process for production of semi-moist cranberries that involves vacuum drying Application of vacuum drying causes the heating of material from inside the chamber. This results in a rapid increase in raw material temperature to a value depending on the pressure occurring in the chamber [Drouzas \& Schubert, 1996].

A low pressure in the chamber protects biological material against overheating and simultaneously increases the intensity of water evaporation from the whole volume of that 
material. As a consequence, the rate of drying is considerably higher than in traditional methods of dehydration [Sharma \& Prassad,2004]. An additional, crucial factor effecting the drying kinetics is the wattage of oven [Andies et al, 2004; Figiel, 2006]. At a substantially deduced pressure in the chamber and heating the material from the inside causes an increase of pressure inside the cells, there occurs the so called "puffing".

During rehydration water penetrates into the material interior and cellular structure being reconstructed, which is accompanied by simultaneous washing out dry matter contained in a material to the surrounding aqueous solution. In order ot make the dried product recover traits of the raw material, it was made of upon dehydration, during rehydration it should absorb the same volume of water that it lost during drying, at possibly marginal loss of dry matter [Lewicki, 1998]. The quality of the dried product is indicated by its color [Yongsawatdigul, \& Gunasekaran, 1996].

It is very important to define the conditions under which the characteristics of fresh apples can be stored [Velic et al. 2004]. Therefore, undertaken research was aimed at determining kinetics of apple slices with vacuum oven method as well as demonstrating the effect of drying shrinkage, quality of rehydration, colour of the dried product and bulk density.

\section{MATERIALS AND METHODS}

The apple varieties used for this study, were selected based on their availability and were obtained from local market Shalimar Srinagar of $J \& K$ and namely red delicious and golden delicious. A total of $10 \mathrm{~kg}$ of apples of each variety were used for this study. The average size of red delicious was $210 \mathrm{gm}$ and that of golden delicious was $270 \mathrm{gm}$.

After procurement apples were stored at $4^{\circ} \mathrm{C}$ in a refrigerator. Apples were washed with tap water. Care was taken so that the chosen apples were free from blemishes, bruises or any kind of physical damage.

The central cores of the apples were removed using a core borer of diameter $15 \mathrm{~mm}$. The core borer was made of stainless steel. Apple slices of each variety were sliced into $4 \mathrm{~mm}, 5 \mathrm{~mm}$ and $6 \mathrm{~mm}$ respectively using a hand operated slicer made of stainless steel. Pretreatment of sliced apples was done using a solution of $0.5 \%$ strength sodium metabisulphate which is a reducing agent.

\section{Determination of moisture content}

The initial moisture content was determined by infrared moisture meter. The infrared moisture meter used was Toshiba (India) and representative sample used was $10 \mathrm{gms}$. 
The result obtained by the moisture meter was cross checked using the following analytic formula (AOAC 1990).

Initial moisture content $(\%$ w.b $)=\frac{\text { Initial weight }- \text { Final weight }}{\text { Initial weight }}$

The procedure was replicated thrice to obtain average value. The final moisture content was determined using the same analytic formula (AOAC 1990).

All the slices were dried up to an average moisture content of $12 \%$.

\section{Vacuum dryer}

A laboratory scale vacuum dryer of model having temperature range $50^{\circ} \mathrm{C}-130^{\circ} \mathrm{C}$ was used in this study. Vacuum chamber is robust stainless steel supplied with two stainless steel shelves insulated with super fine mineral wool with toughened glass sealing into a neoprene rubber gasket. The door closure is 3 screw threaded catch. One diaphragm valve and a vacuum gauge are provided. Temperature is controlled by electronic digital temperature indicator cum controller range $50{ }^{\circ} \mathrm{C}$ to $130{ }^{\circ} \mathrm{C}$. An indicator lamp shows the operation of the heater. Size inside chamber (stainless steel) with $22.5 \mathrm{~cm}$ diameter, $30 \mathrm{~cm}$ depth and 12 liters capacity.

\section{Pump specifications}

- Motor capacity (hp) : 0.25

- Dimensions (mm) : 308 x124 x 230

- Flow rate (lpm) : 42

"NSW" Vacuum pumps are widely used in the Laboratory. The key features include:

- High vacuum, high pump speed and reduces evacuation time.

- The pump body has integrated design and anti-suck back design and easy to handle.

\section{Determination of response variables}

The quality evaluation of the dried product was carried out on the basis of response variables viz. Shrinkage, Rehydration Ratio, Colour change, Bulk Density and Over All Acceptability.

Shrinkage

Drying shrinkage was evaluated by determining relative volume of dried material being a ratio of apple samples volume after drying and before drying.

$$
\text { Shrinkage }=\frac{\mathrm{Va}-\mathrm{Vo}}{\text { Vo }}
$$

Where 
$\mathrm{Va}$ is the final volume

Vo represents the initial volume.

The volume of apples samples was measured by the use of measuring cylinder with toluene. Three replications were performed on samples.

Rehydration of dried apples was carried out in distilled water with a temperature of $21^{\circ} \mathrm{C}$ for 210 minutes. After which the samples were taken out from distilled water and were dried with blotting paper and measuring its weight with electronic balance with precision up to $0.001 \mathrm{gm}$.

\section{Rehydration ratio}

The quality if rehydration was presented with the use of following parameters [ Lewicki , 1998; Le Loch-Bonazzi et.al 1992]: Water absorption capacity (WAC) dry matter holding capacity (DHC) as well as rehydration ability (RA).

$$
\text { Rehydration Ratio }=\frac{\text { Weight of rehydrated product }}{\text { Weight of the dried sample }}
$$

The WAC was computed by dividing the mass of water absorbed during dehydration by the mass of water removed in the drying process. The DHC expressed the capacity of material for retaining soluble substances and was computed by dividing dry matter content of the sample after rehydration by dried matter content of the sample before rehydration.

On termination of the rehydration test the hydrated samples were dried to enable determination of that part of dried matter which penetrated into the solution during rehydration. The RA was a product of WAC and DHC.

\section{Color change}

The colour of the dried sample was evaluated in three replications with the use of a hand held Color Tec-PCM reflective colorimeter. Apples of both varieties were placed in dark room in order to determine the color parameters without affecting the result as presence of other wavelengths may alter the result to a greater extent.

$$
\Delta \mathrm{E}=\sqrt{(\mathrm{L}-\mathrm{L} *)^{2}+(\mathrm{a}-\mathrm{a} *)^{2}+(\mathrm{b}-\mathrm{b} *)^{2}}
$$

Where

$\Delta \mathrm{E}$ is the colour change.

L, a and b represents Lightness, Redness and Yellowness.

$\mathrm{L}^{*}, \mathrm{a}^{*}$ and $\mathrm{b}^{*}$ represents final Lightness, Redness and Yellowness. 


\section{Bulk density}

The initial and final bulk density of each sample was determined using toluene which is a flammable liquid with a specific gravity $(\mathrm{G})$ of 0 . 865. The bulk density of samples was determined by weighing the samples and then placing them in a container with a determined volume, filled with toluene [ Baysal et at,2003]. The bulk density was determined via the ratio of the samples weight to the volume expanded.

$$
\text { Bulk Density }=\frac{\text { Weight of sample }}{\text { Volume expanded }}
$$

\section{Drying models}

Drying curves obtained were fitted to the following dying models namely Pages' model, Logarithms model and Wang and Singh model respectively.

\section{Page Model: $\mathbf{M R}=\exp \left(-\mathbf{k t} \mathbf{t}^{\mathbf{m}}\right)$}

Logarithms Model: $\mathbf{M R}=\mathbf{a} \exp (-\mathbf{k t})+\mathbf{c}$

Wang and Singh Model: $\mathbf{M}_{\mathbf{R}}=\mathbf{1}+\mathbf{a t}+\mathbf{b t}^{\mathbf{2}}$

Moisture ratio MR is given as follows

$$
\mathrm{MR}=\frac{M-M_{e}}{M_{o-M_{e}}}
$$

Where MR is the dimensionless moisture ratio;

$\mathrm{M}$ is the moisture content at any time in \% w.b

$\mathrm{M}_{\mathrm{e}}$ is the equilibrium moisture content in $\%$ w.b

$\mathrm{M}_{\mathrm{o}}$ is the initial moisture content in $\% \mathrm{w} . \mathrm{b}$

However, MR is the simplified to $\mathrm{M} / \mathrm{Mo}$ in place of moisture ratio equation since the relative humidity of the drying air fluctuated continuously inside drying chamber (Diamente and Munro 1993).

The constants of models tested where determined by nonlinear regression analysis. The estimation method was Quasi-Newton and the adequacy of models was evaluated and compared by means of the coefficient of determination $\mathrm{R}^{2} . \mathrm{R}^{2}$ was used as a primary comparison criterion for selecting the best model to fit the models tested to the experimental data.

\section{RESULTS}


International Journal of Agriculture and Environmental Research

ISSN: 2455-6939

Volume: 06, Issue: 03 "May-June 2020"

Experiments were conducted to categorize the effect of drying behavior of apple slices having thickness $4 \mathrm{~mm}, 5 \mathrm{~mm}$ and $6 \mathrm{~mm}$ were evaluated at two air temperatures viz. $90^{\circ} \mathrm{C}$ and $100^{\circ} \mathrm{C}$ and response variables namely Shrinkage, Rehydration Ratio, Colour change, Bulk Density and Over All Acceptability were determined and the detailed result and their discussion are as follows:

\section{Drying kinetics}

The total drying time for variant $4 \mathrm{~mm}, 5 \mathrm{~mm}$ and $6 \mathrm{~mm}$ at temperatures $90^{\circ} \mathrm{C}$ and $100^{\circ} \mathrm{C}$ respectively are as follows:

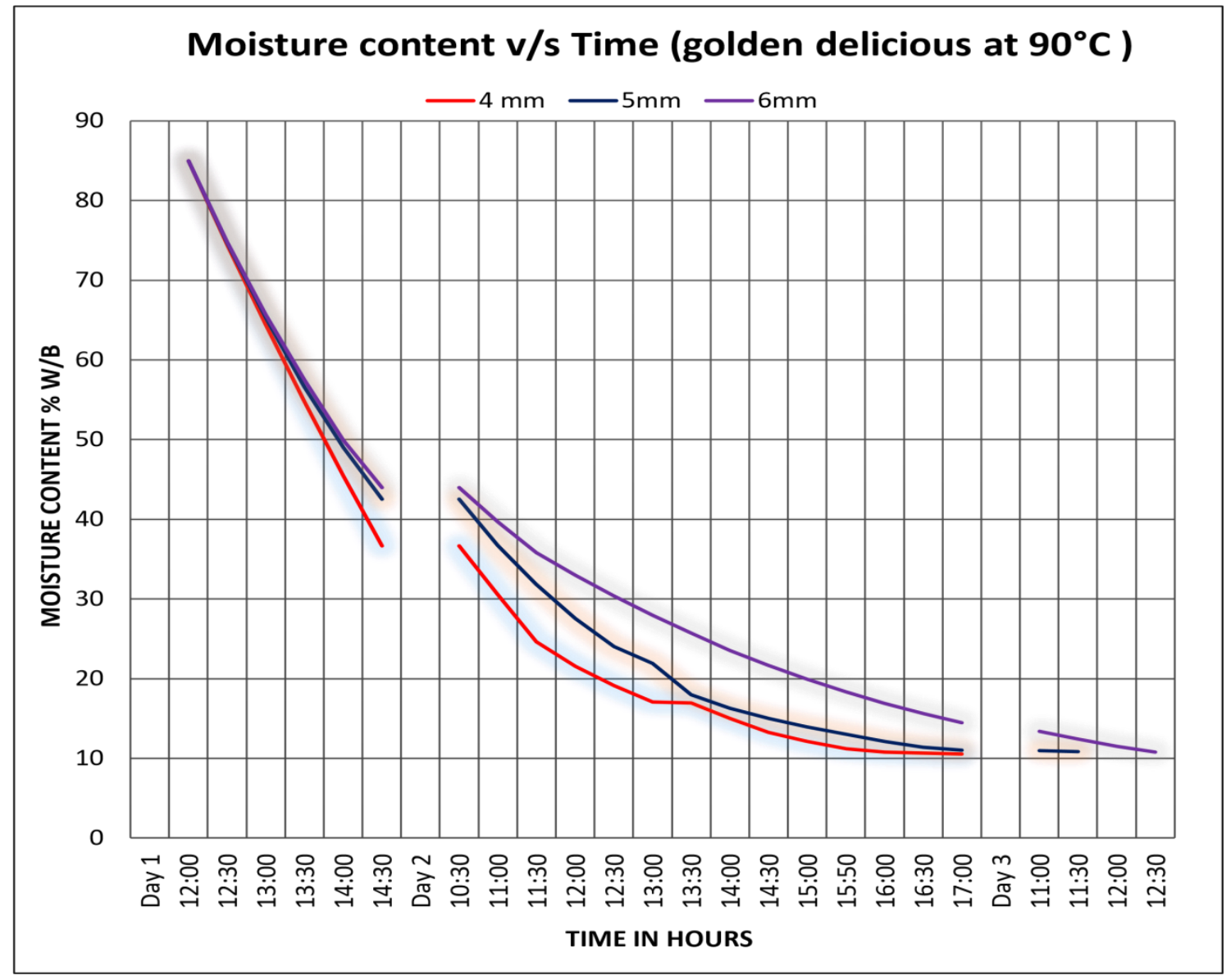


International Journal of Agriculture and Environmental Research

ISSN: 2455-6939

Volume: 06, Issue: 03 "May-June 2020"

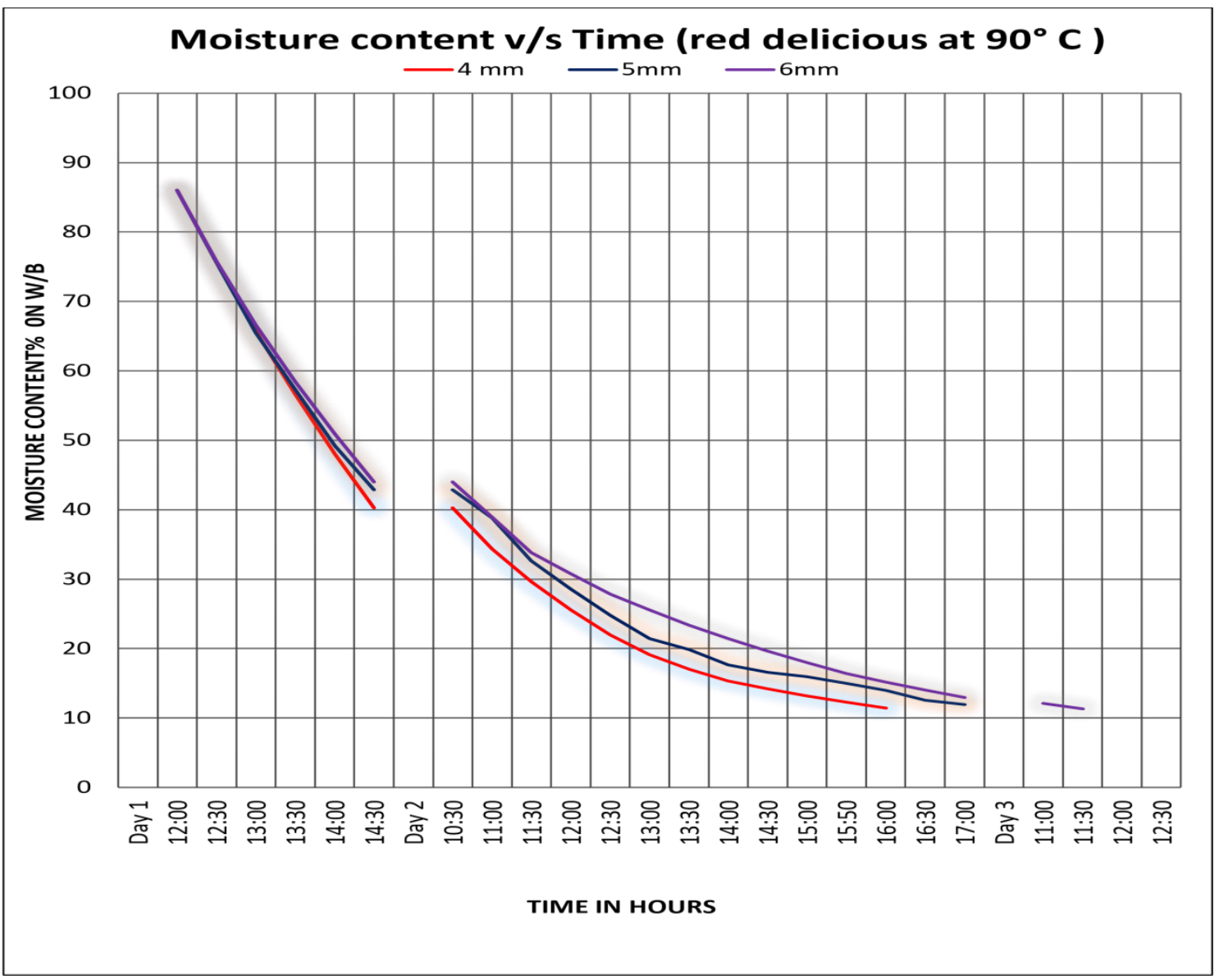


International Journal of Agriculture and Environmental Research

ISSN: 2455-6939

Volume: 06, Issue: 03 "May-June 2020"

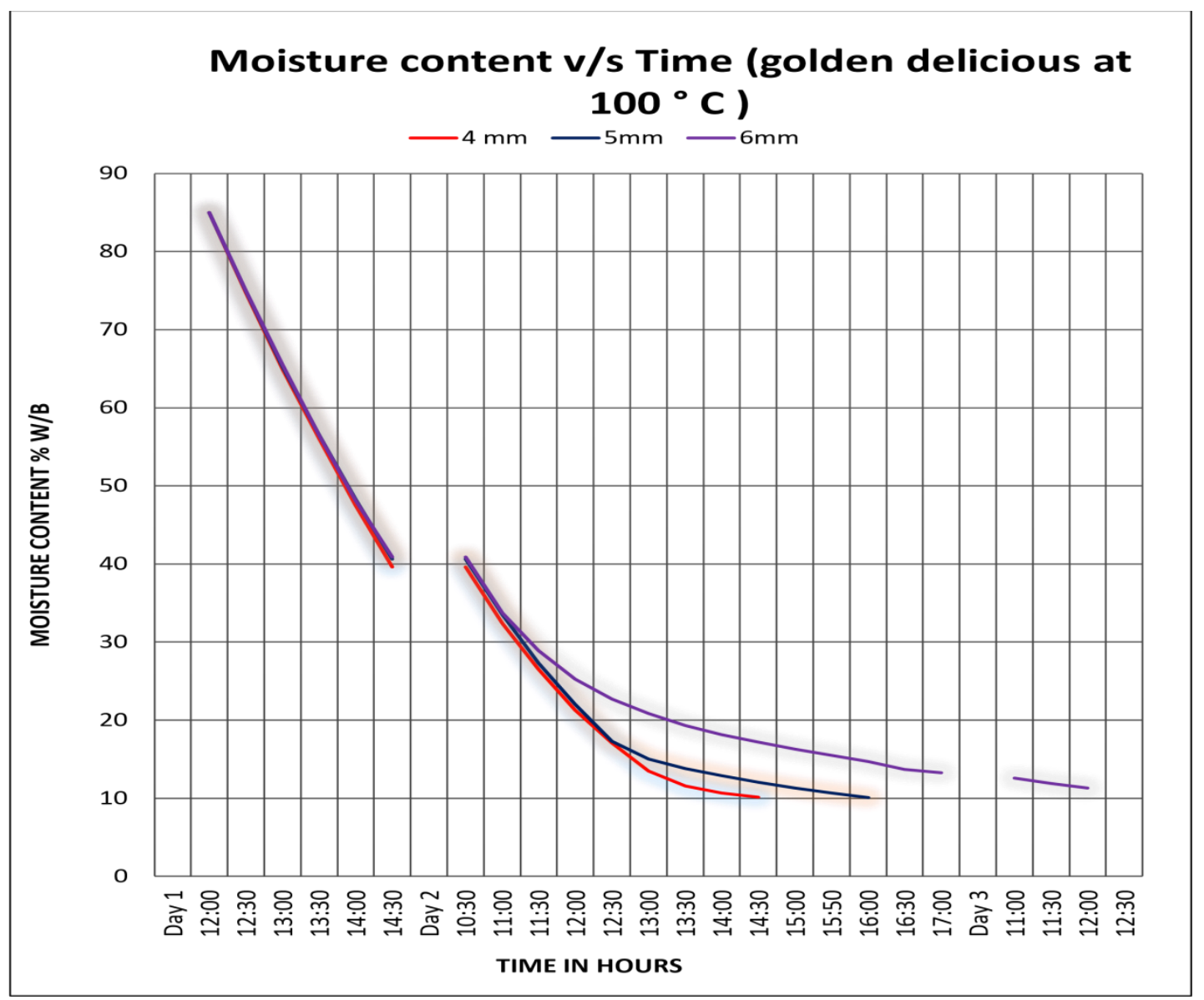


International Journal of Agriculture and Environmental Research

ISSN: 2455-6939

Volume: 06, Issue: 03 "May-June 2020"

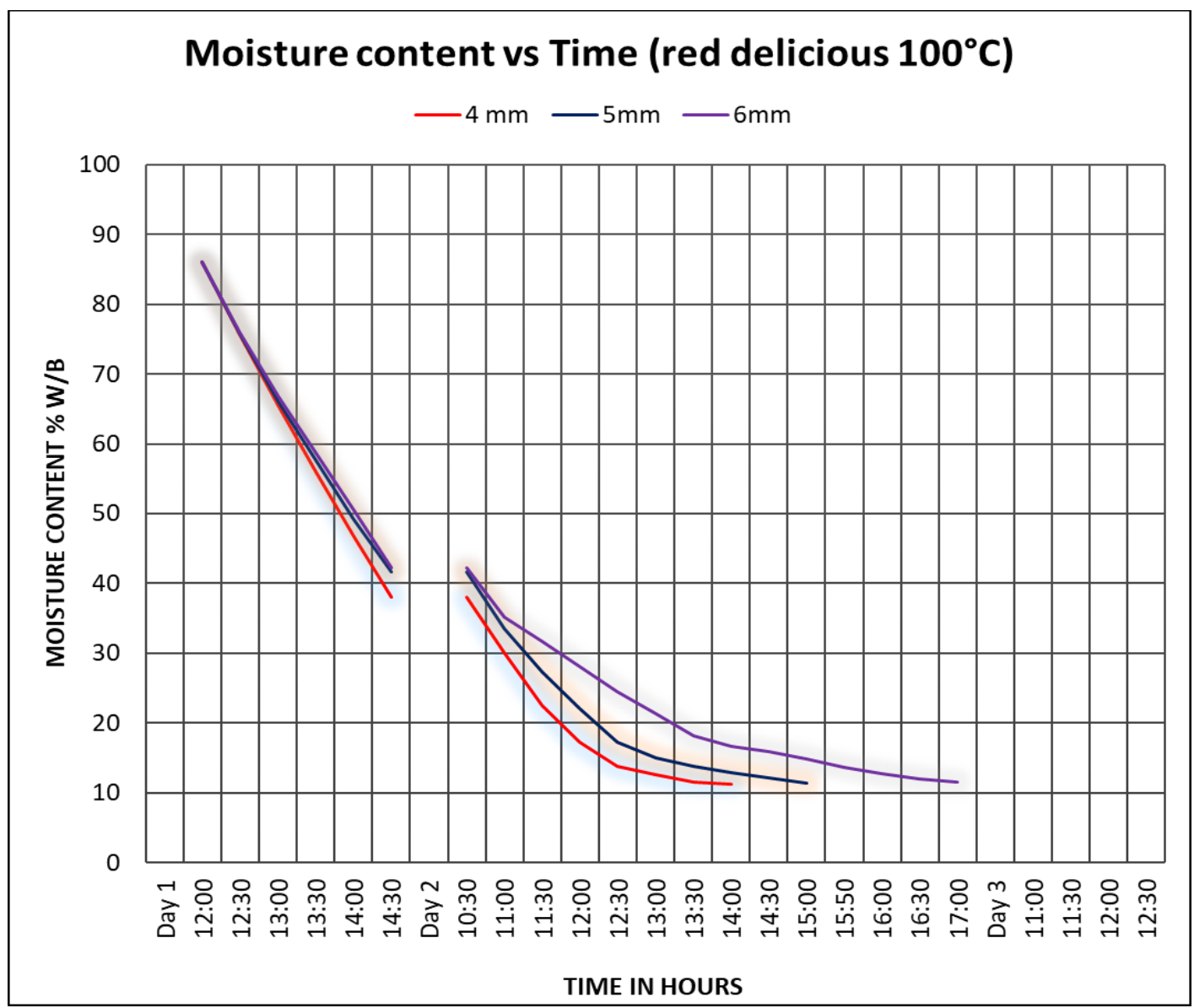

In the above plots between moisture content and time, it is very evident that the preheating/built up time is very less. This is due to the reason that the operating temperatures $\left(90^{\circ} \mathrm{C}\right.$ and $\left.100^{\circ} \mathrm{C}\right)$ are fairly high and quickly heat up the apple sample. A clear constant drying curve is visible till time $\mathrm{T}=14: 30$, Day 1(2.5 hours from the start of procedure) following which the drying rate retards and results in the commencement of first falling rate period marked by the first critical point located at the end of constant rate drying curve (at $\mathrm{T}=10: 30$, Day 2).

In the initial phase of drying with vacuum oven method, the water losses was relatively rapid. In the comparative study of dried apples using hot air, intermittent and continuous microwave, Maskaan [2000] reported that during the subsequent drying dynamics of water loss decreases and the drying with that method begins to be time consuming. It must be noted that the gap left in the plot at the end of Day 1 and Day 2 is because the procedure was stopped during this period and the samples were stored in the desiccators to prevent any unnecessary uptake of moisture.

As the drying proceeds, the drying rates further suffer a depreciation and the end of first falling rate period marks the beginning of the second critical point followed by second falling rate 
period. These observation has also been reported by Dilip M.Parikh [Dilip, 2015] for vacuum oven drying of cranberries.

\section{Volumetric shrinkage}

The volumetric shrinkage for all three variants at temperatures $90^{\circ} \mathrm{C}$ and $100^{\circ} \mathrm{C}$ are tabulated as:

\begin{tabular}{|l|l|l|l|l|l|l|}
\hline \multirow{2}{*}{ Variety } & \multicolumn{4}{l|}{ Volumetric Shrinkage (\%) } & \multicolumn{3}{l|}{ Volumetric Shrinkage (\%) } \\
& $90^{\circ} \mathrm{C}$ & \multicolumn{2}{l|}{$100^{\circ} \mathrm{C}$} & \\
\hline & $4 \mathrm{~mm}$ & $5 \mathrm{~mm}$ & $6 \mathrm{~mm}$ & $4 \mathrm{~mm}$ & $5 \mathrm{~mm}$ & $6 \mathrm{~mm}$ \\
\hline Golden Delicious & $70.33 \%$ & $77.12 \%$ & $80.2 \%$ & $69.98 \%$ & $74.18 \%$ & $78.6 \%$ \\
\hline Red Delicious & $71.86 \%$ & $76.46 \%$ & $78.81 \%$ & $68.39 \%$ & $70.01 \%$ & $74.38 \%$ \\
\hline
\end{tabular}

Volumetric Shrinkage

Volumetric shrinkage is maximum for $6 \mathrm{~mm}$ slices, followed by $5 \mathrm{~mm}$ and $4 \mathrm{~mm}$ slices respectively. The possible reason behind this observation is the case hardening of relatively thinner slices which prevents any further change in volume. Thus $4 \mathrm{~mm}$ slices showed lower values of volumetric shrinkage as compared to $5 \mathrm{~mm}$ and $6 \mathrm{~mm}$ slices respectively. This might be due to the fact that slow drying reduces internal stresses, which in consequence results in increased shrinkage. Applying high temperatures, however, increase internal stresses but at the same time the resulting fast drying leads to a mechanical stabilization of the surface [Barbara et al. 2013].

This trend is same for both the species of apple used in this study.

When air temperature is kept constant, shrinkage is significantly higher than that of comparison specimen which is initially dried at a high temperature [Barbara et al. 2013]

Drying with vacuum oven method caused an increase in Vs and consequently, a reduction in drying shrinkage.

The apples were soft during the course of drying and became hard after cooling down. According to Bhandari and Howes (1999), in drying of high sugar products, if the drying temperature is higher than glass transition temperature, the product probably will be soft during the process. After cooling, it will harden, as its temperature drops below glass transition temperature. This behavior was observed for all treated apple samples. When the samples were removed from the air drier or vacuum oven, they were in a rubbery state until they reached the ambient temperature. Thus, the shrinkage during drying can be interpreted as a structural change of the 
amorphous part of the product due to the exposition to a process temperature above glass transition temperature, as discussed by Roos (1995).

\section{Rehydration ratio}

The rehydration ratio for all three variants at temperatures $90^{\circ} \mathrm{C}$ and $100^{\circ} \mathrm{C}$ are tabulated as:

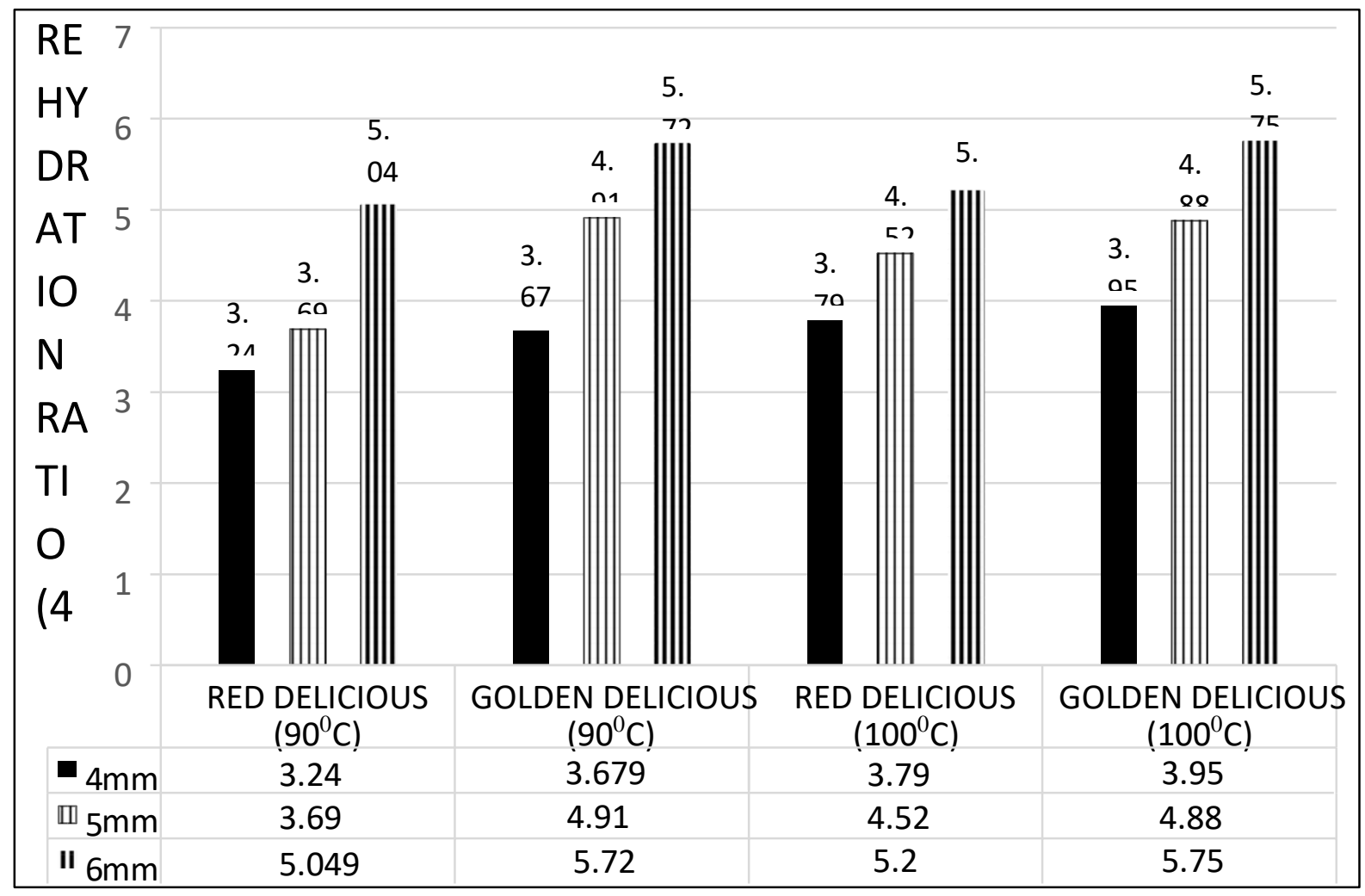

The dried product rehydration characteristics can be used as a quality indicator. The rehydration ratio was found higher in $6 \mathrm{~mm}$ thick slices than $5 \mathrm{~mm}$ and $4 \mathrm{~mm}$ respectively. The results obtained showed higher water absorption capacity and with improved dry matter holding capacity and rehydration ability of dried samples and are in accordance with Adam Figiel [2007].

Fruits and vegetables dried with the use of vacuum oven dryer usually demonstrate better rehydration properties than those dried only in air [Maskan, 2000; Khraishehn et at, 2004; Prabhanjan et at., 1995].

\section{Colour change}

The initial, final and total color change for all three variants at temperatures $90^{\circ} \mathrm{C}$ and $100^{\circ} \mathrm{C}$ are tabulated as: 
International Journal of Agriculture and Environmental Research

ISSN: 2455-6939

Volume: 06, Issue: 03 "May-June 2020"

\begin{tabular}{|l|l|l|l|l|l|l|}
\hline Variety & \multicolumn{3}{|l|}{ Golden Delicious } & \multicolumn{2}{l|}{ Red Delicious } \\
\hline Parameters & Initial & $\begin{array}{l}\text { Final } \\
(\mathbf{t e m p} \\
\mathbf{9 0} \mathbf{C})\end{array}$ & $\begin{array}{l}\text { Final } \\
\left(\begin{array}{l}\text { temp } \\
\left.\mathbf{1 0 0}^{\circ} \mathbf{C}\right)\end{array}\right.\end{array}$ & Initial & $\begin{array}{l}\text { Final } \\
(\text { temp } \\
\left.\mathbf{9 0}^{\circ} \mathbf{C}\right)\end{array}$ & $\begin{array}{l}\text { Final } \\
\left(\begin{array}{l}\text { temp } \\
\left.\mathbf{1 0 0}^{\circ} \mathbf{C}\right)\end{array}\right.\end{array}$ \\
\hline L & 73.7 & & & 58.5 & & \\
\hline a & -0.37 & & & -0.29 & & \\
\hline b & 29.52 & & & 33.38 & & \\
\hline L $^{*}$ & & 36.8 & 32.8 & & 35.4 & 30.6 \\
\hline $\mathrm{a}^{*}$ & & 0.140 & 0.503 & & 0.403 & 0.612 \\
\hline $\mathrm{b}^{*}$ & & 52.3 & 51.8 & & 47.2 & 42.6 \\
\hline$\Delta \mathrm{E}$ & & 43.36 & 46.58 & & 26.92 & 29.39 \\
\hline
\end{tabular}

Initial and Final Colour difference for Golden delicious and Red delicious at $90^{\circ} \mathrm{C}$ and $100^{\circ} \mathrm{C}$

Results of measurement were presented as the values of the following parameters:

$\Delta \mathrm{E}, \mathrm{L}, \mathrm{a}, \mathrm{b}, \mathrm{L}^{*}, \mathrm{a}^{*}$ and $\mathrm{b}^{*}$.

Where

$\Delta \mathrm{E}$ is the Colour change.

$\mathrm{L}, \mathrm{a}$ and $\mathrm{b}$ represents initial Lightness, Redness and Yellowness.

$\mathrm{L}^{*}, \mathrm{a}^{*}$ and $\mathrm{b}^{*}$ represents final Lightness, Redness and Yellowness.

The Equation used for computation of total color change is given below:

$$
\Delta \mathrm{E}=\sqrt{(\mathrm{L}-\mathrm{L} *)^{2}+(\mathrm{a}-\mathrm{a} *)^{2}+(\mathrm{b}-\mathrm{b} *)^{2}}
$$

Colour is one of the most important aspects in determination of product quality [Barbara et al., 2013]. Yongsawatdigul, \& Gunasekaran, [1996] suggested that the quality of the dried product is indicated by its colour.

Colour result involves that the apple tissue underwent extensive homogeneous colour change.

Dried apples of both varieties were slightly darker than the fresh apples.

The red delicious variety was relatively darker than Golden delicious. Similar findings have been reported for "Dehydration of apples by a combination of convective and vacuum microwave drying" which suggests that measurement of color demonstrated that the process of drying, 
irrespective of the method applied, caused considerable darkening able darkening of apple cubes (a decrease of L parameter)[ Drouzas et al. 1996].

The possible reason for darkening is caramelization which may have taken place during the course of drying.

The findings by Nahid [2015] in "Comparative study of dried apples using hot air, intermittent and continuous microwave" suggested that a significant increase in color change value could happen with an increase in the temperature for "Vacuum drying of cranberries".

\section{Bulk density}

The initial and final bulk density for $4 \mathrm{~mm}, 5 \mathrm{~mm}$ and $6 \mathrm{~mm}$ at temperatures $90^{\circ} \mathrm{C}$ and $100^{\circ} \mathrm{C}$ are tabulated as:

\begin{tabular}{|c|c|c|c|c|c|c|c|c|c|c|c|c|}
\hline Variety & \multicolumn{3}{|c|}{$\begin{array}{c}\text { Initial Bulk } \\
\text { Density } \\
(\mathrm{gm} / \mathrm{ml}) \\
90^{\circ} \mathrm{C}\end{array}$} & \multicolumn{3}{|c|}{$\begin{array}{c}\text { Final Bulk } \\
\text { Density } \\
(\mathrm{gm} / \mathrm{ml}) \\
9^{\circ} \mathrm{C}\end{array}$} & \multicolumn{3}{|c|}{$\begin{array}{c}\text { Initial Bulk } \\
\text { Density } \\
(\mathrm{gm} / \mathrm{ml}) \\
\mathbf{1 0 0}^{\circ} \mathrm{C}\end{array}$} & \multicolumn{3}{|c|}{$\begin{array}{c}\text { Final Bulk } \\
\text { Density } \\
(\mathrm{gm} / \mathrm{ml}) \\
\mathbf{1 0 0}^{\circ} \mathrm{C}\end{array}$} \\
\hline Thickness & $4 \mathrm{~mm}$ & $5 \mathrm{~mm}$ & $6 \mathrm{~mm}$ & $4 \mathrm{~mm}$ & $5 \mathrm{~mm}$ & $6 \mathrm{~mm}$ & $4 \mathrm{~mm}$ & $5 \mathrm{~mm}$ & $6 \mathrm{~mm}$ & $4 \mathrm{~mm}$ & $5 \mathrm{~mm}$ & $6 \mathrm{~mm}$ \\
\hline Golden Delicious & 0.8415 & 0.8415 & 0.8415 & 0.7325 & 0.695 & 0.654 & 0.8415 & 0.8415 & 0.8415 & 0.712 & 0.679 & 0.635 \\
\hline Red Delicious & 0.895 & 0.895 & 0.895 & 0.722 & 0.685 & 0.651 & 0.895 & 0.895 & 0.895 & 0.702 & 0.662 & 0.652 \\
\hline
\end{tabular}

Initial and final bulk density of Red and Golden Delicious apples

The $4 \mathrm{~mm}$ slices show relatively higher values of bulk density than $5 \mathrm{~mm}$ and $6 \mathrm{~mm}$ slices respectively. The explanation behind this observation lies in the case hardening of $4 \mathrm{~mm}$ slices which causes the final bulk density to exhibit relatively greater value for thinner slices as compared to thicker slices.

It must be noted that the decrease in trend of bulk density with the increase in temperature is in agreement with findings of Kharaisheh [2004], Pimpaporn [2007] and Thuwapanichayanan [2011] in "Quality and structural changes in starchy foods during microwave and convective drying".

The results of bulk density obtained using toluene are in agreement with Krokida [1997]. The densities found in this work could be compared to those reported by Krokida and Maroulis (1997) and Krokida et al. (1997), although equipment configuration, drying conditions and apple 
International Journal of Agriculture and Environmental Research

ISSN: 2455-6939

Volume: 06, Issue: 03 "May-June 2020"

variety are different. The authors have obtained, for apple cylinders (approximately 2.10-2 m diameter and 1.10-2 $\mathrm{m}$ height) vacuum dried and air dried $\left(70^{\circ} \mathrm{C}\right)$, values for bulk density around 20 to 50\% lower, suggesting that thin slices could make shrinkage easier. The results are in agreement with the findings of Maria Aparecida [2014] for "Vacuum drying of osmotic dehydrated apple slices" which suggests that the vacuum dried samples, presented higher densities and higher volume reduction, reflecting the collapsing of the solid matrix. The vacuum dried samples remained wet for longer time.

\section{Moisture ratio}

The changes in moisture ratio with respect to time at temperature $90^{\circ} \mathrm{C}$ and $100^{\circ} \mathrm{C}$ are as under:
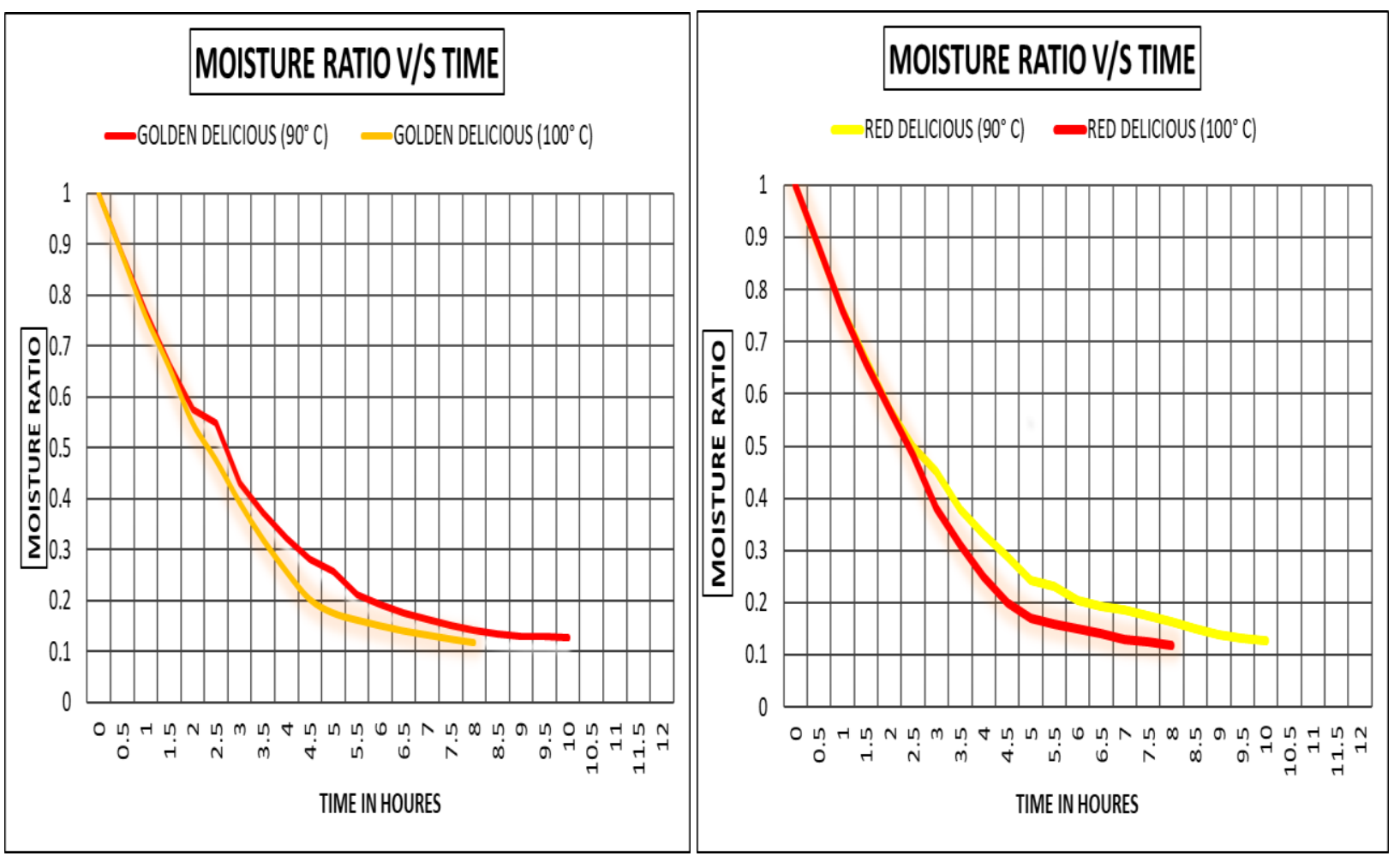

However, $M_{R}$ is the simplified to $M / M o$ in place of moisture ratio equation since the relative humidity of the drying air fluctuated continuously inside drying chamber as reported by Diamente and Munro [1993] for "Mathematical modelling of thin layer of solar drying of sweet potato slices".

In the initial phase of drying at both temperatures (i.e $90^{\circ} \mathrm{C}$ and $100^{\circ} \mathrm{C}$ ) with vacuum oven method, water loss is relatively rapid. Yet during subsequent drying dynamics of water loss decreases and drying with that method begins to be time consuming [Maskan,2000] . 
International Journal of Agriculture and Environmental Research

ISSN: 2455-6939

Volume: 06, Issue: 03 "May-June 2020"

\section{Model fitting}

Drying data obtained were fitted to the dying models namely Page model, Logarithmic model and Wang and Singh model and analyzed for their suitability to express the drying behavior of apple slices on the basis of coefficient of determination and standard error of estimate. Similar procedure has been followed by Ahmet [2005] for solar tunnel drying of apple slices The results are mentioned as under:

\begin{tabular}{|l|l|l|l|l|l|l|}
\hline & \multicolumn{2}{|l|}{ Page model } & \multicolumn{2}{l|}{ Logarithmic model } & \multicolumn{2}{l|}{ Wang and Singh model } \\
\hline & $90^{\circ} \mathrm{C}$ & $100^{\circ} \mathrm{C}$ & $90^{\circ} \mathrm{C}$ & $100^{\circ} \mathrm{C}$ & $90^{\circ} \mathrm{C}$ & $100^{\circ} \mathrm{C}$ \\
\hline $\mathrm{R}^{2}$ & 99.44 & 99.18 & 99.16 & 99.145 & 98.87 & 99.735 \\
\hline S.E.E & 0.0205 & 0.0265 & 0.025 & 0.028 & 0.0285 & 0.015 \\
\hline
\end{tabular}

The equation constants for Page model, Logarithmic model and Wang and Singh model determined by nonlinear regression analysis are mentioned as under:

\begin{tabular}{|l|c|c|c|c|c|c|c|c|c|c|}
\hline & \multicolumn{2}{l|}{$\mathrm{k}$} & $\mathrm{N}$ & $\mathrm{k}$ & \multicolumn{2}{l|}{$\mathrm{l}$} & \multicolumn{2}{l|}{$\mathrm{c}$} \\
\hline Variable & $90^{\circ} \mathrm{C}$ & $100^{\circ} \mathrm{C}$ & $90^{\circ} \mathrm{C}$ & $100^{\circ} \mathrm{C}$ & $90^{\circ} \mathrm{C}$ & $100^{\circ} \mathrm{C}$ & $90^{\circ} \mathrm{C}$ & $100^{\circ} \mathrm{C}$ & $90^{\circ} \mathrm{C}$ & $100^{\circ} \mathrm{C}$ \\
\hline Page model & 0.298 & 0.28 & 0.9105 & 1.075 & & & & & & \\
\hline Logarithmic model & 0.257 & 0.3185 & & & 0.5725 & 0.589 & & & 0.538 & 0.558 \\
\hline $\begin{array}{l}\text { Wang and Singh } \\
\text { model }\end{array}$ & & & & -0.219 & -0.2565 & 0.0135 & 0.0185 & & \\
\hline
\end{tabular}

Similar results have been reported by Schirmer et at. [1996] for drying of banana, Bala and Mondol [2001] for fish and Bala et al. [2003] for pineapple.

For $90^{\circ} \mathrm{C}$, Pages Model suits the best followed by Logarithmic Model and Wang and Singh Model. For $100^{\circ} \mathrm{C}$, Wang and Singh Model suits the best followed by Pages Model and Logarithmic Model. The above results were carried out using experimental data of Red Delicious Apples where as in case of Golden Delicious almost same results were obtained.

\section{Mean sensory score of apple slices}

The sensory evaluation was performed by a panel consisting of five members. All the members were provided the samples belonging to same apple of both varieties. The parameters to be considered were appearance, taste, texture and crispness. 
International Journal of Agriculture and Environmental Research

ISSN: 2455-6939

Volume: 06, Issue: 03 "May-June 2020"

Below are the results as obtained from the study:

\begin{tabular}{|l|l|l|l|l|}
\hline Sensorial attributes & Appearance & Texture & Crispness & Taste \\
\hline Average & 6 & 7 & 8 & 9 \\
\hline
\end{tabular}

A Hedonic scale was used to evaluate the sensory characteristics.

\section{CONCLUSION}

Vacuum oven dryer is capable of dehydration of apple under climatic conditions of Kashmir. The moisture content was reduced from an average moisture content of $85 \%$ (w.b) in Golden Delicious to about $12 \%$ (w.b) in about 9, 10and 11 hours for $4 \mathrm{~mm}, 5 \mathrm{~mm}$, and $6 \mathrm{~mm}$ thick samples respectively. Likewise, the moisture content was reduced from an average moisture content of $86 \%$ (w.b) in Red Delicious to about 12\% (w.b) about 8, 9 and 9.5 hours for $4 \mathrm{~mm}, 5 \mathrm{~mm}$, and $6 \mathrm{~mm}$ thick samples respectively. Higher drying rates are seen with the increase in drying temperature and decrease in sample thickness.

Among all samples, golden delicious apples, $6 \mathrm{~mm}$ thick, dried at $90^{\circ} \mathrm{C}$ underwent minimum colour change. For same temperature and thickness, golden delicious had the highest rehydration ratio. A decrease in trend of bulk density with the increase in temperature was seen. Volumetric shrinkage is maximum for $6 \mathrm{~mm}$ slices, followed by $5 \mathrm{~mm}$ and $4 \mathrm{~mm}$ slices respectively. For same temperature and thickness red delicious dried quickly in comparison to golden delicious. For vacuum oven drying of apple slices, Page's model was considered to be best fit at $90^{\circ} \mathrm{C}$ and Wang and Singh model for $100^{\circ} \mathrm{C}$ respectively. It is expected that the above stated findings will help growers to improve the quality of the dried apple product at an industrial scale. Further studies are going on.

\section{REFERENCES}

Eliçin, Ahmet \& Sacilik, Kamil. (2005). An experimental study for solar tunnel drying of apple. Tarim Bilimleri. 11. 207-211.

Mathlouthi, Mohamed. (2001). Water content, water activity, water structure and the stability of foodstuffs. Food Control. 12. 409-417. 10.1016/S0956-7135(01)00032-9.

Akpinar E. K., and Bicer Y.. 2005. Modelling of the drying of eggplants in thin-layers. Int. J. Food Sci. Technol. 40:273-281.

Van Arsdel W. 1973. Drying phenomena. Food Dehydration. 2:27-33. 
International Journal of Agriculture and Environmental Research

ISSN: 2455-6939

Volume: 06, Issue: 03 "May-June 2020"

Yongsawatdigul, J. and Gunasekaran, S., Microwave-vacuum drying of cranberries: Part I. Energy use and efficiency, Journal of Food Processing and Preservation. Vol. 20, pp.121143 (1996).

Drouzas A.E., Schubert H., Microwave application in vacuum drying of fruits. J. Food Eng., 1996, 28, 203-209.

Sharma G.P., Prasad S., Effective moisture diffusivity of garlic cloves undergoing microwaveconvective drying. J. Food Eng., 2004, 65, 609-617.

Andres A., Bilbao K., Fito P., Drying kinetics of apple cylinders under combined hot air microwave dehydration. J. Food Eng., 2004, 63, 71-78.

Figiel, A., Drying kinetics and drying shrinkage of garlic subjected to vacuum - microwave dehydration. Acta Agrophysica, 2006, 7, 49-58.

Figiel A., Szarycz M., Świerk B., Vacuum-microwave drying of apples. Inż. Roln., 2006, 2, $293-$ 298 (in Polish; English abstract).

Lewicki P.P., Some remarks on rehydration of dried foods. J.a Food Eng., 1998, 36, 81-87.

Baysal T., Icier F., Ersus S., and Yildız H. 2003. Effects of microwave and infrared drying on the quality of carrot and garlic. Eur. Food Res. Technol. 218:68-73.

Krokida M., and Maroulis Z. 1997. Effect of drying method on shrinkage and porosity. Drying Technol. 15:2441-2458.

Diamente, L. M. and P. A. Munro. 1993. Mathematical modeling of the thin layer solar drying of sweet potato slices. Solar Energy 51 (4): 271-276.

Parikh, Dilip. (2015). Vacuum Drying: Basics and Application. Chemical Engineering. 122.

Mauro, Maria \& M. Monnerat, Sandra \& E. Rodrigues, Alan. (2004). Vacuum drying of osmotic dehydrated apple slices.

Durance T.D., Wang J.H., Energy consumption, density, and rehydration rate of vacuum microwave- and hot-air convection dehydrated tomatoes. J. Food Sci., 2002, 67, 22122216.

Lin T.M., Durance T.D., Scaman C.H., Characterization of vacuum microwave, air and freeze dried carrot slices. Food Res. Int., 1998, 31, 111-117.

Rms. Y. 1993. Melting and Glass Transition of Low Molecular Weight Cahhydnlcs, Carbohydr. Rcs., 238 pp. 3948. 
Bhandari, B. R., \& Howes, T. (1999). Implication of glass transition for the drying and stability of dried foods. Journal of Food Engineering, 40(1-2), 71-79

Roos, Y. H. (1995). Glass transition-related physicochemical changes in foods. Food Technology, October, 97-102.

Roos, Y. (1993). Melting and glass transition of low molecular weight carbohydrates. Carbohydrate Research, 238, 39-48.

AOAC (volume 1), 9CFR 318.19(b), 1990

Pimpaporn P., Devahastin S., and Chiewchan N. 2007. Effects of combined pretreatments on drying kinetics and quality of potato chips undergoing low-pressure superheated steam drying. J. Food Eng.81:318-329.

Thuwapanichayanan R., Prachayawarakorn S., Kunwisawa J., and Soponronnarit S. 2011. Determination of effective moisture diffusivity and assessment of quality attributes of banana slices during drying. LWT-Food Sci. Technol. 44:1502-1510.

P. Schirmer, S. Janjai, A. Esper, R. Smitabhindu, W. Mühlbauer, (1996), Experimental investigation of the performance of the solar tunnel dryer for drying bananas, Renewable Energy, Volume 7, Issue 2, Pages 119-129.

Bala, B K \& R. A. Mondol, M. (2006). Experimental investigation of solar drying of fish using tunnel dryer. DRYING TECHNOLOGY. 19(2). 427-436. 10.1081/DRT-100102915.

Bala, B K \& Mondol, M.R.A. \& Biswas, B.K. \& Das Chowdury, B.L. \& Janjai, S. (2003). Solar drying of pineapple using solar tunnel drier. Renewable Energy. 28. 183-190. 10.1016/S0960-1481(02)00034-4.

Barbara Sturm, Werner C Hofacker, Oliver Hensel Drying Technology 30(14), 1570-1582, 2013

Figiel, A. (2007). Dehydration of apples by a combination of convective and vacuum-microwave drying. Polish journal of food and nutrition sciences, 57, No. 4(A), 131-135.

Khraisheh M.A.M., McMinn W.A.M., Magee T.R.A., Quality and structural changes in starchy foods during microwave and convective drying. Food Res. Int., 2004, 37, 497-503.

Velic, D., M. Planinic, S. Tomas and M. Bilic. 2004. Influence of airflow velocity on kinetics of convection apple drying. Journal of Food Engineering 64 (1): 97-102.

Le Loch-Bonanza C., Wolff E., Gilbert H., Quality of dehydrated cultivated mushrooms (Agaricus bisporus): a comparison between different drying and freeze - drying processes. Leb. Wissen. Tech., 1992, 25, 334-339. 
Aghilinategh, N., Rafiee, S., Gholikhani, A., Hosseinpur, S., Omid, M., Mohtasebi, S. S. and Maleki, N. (2015), A comparative study of dried apple using hot air, intermittent and continuous microwave: evaluation of kinetic parameters and physicochemical quality attributes. Food Sci Nutr, 3: 519-526. doi:10.1002/fsn3.241

Lewicki P.P., Some remarks on rehydration of dried foods. J. Food Eng., 1998, 36, 81-87.

Maskan M., Drying, shrinkage and rehydration characteristics of kiwifruits during hot air and microwave drying. J. Food. Eng., 2001, 46, 177-182.

Maskan M., Microwave/air and microwave finish drying of banana. J. Food Eng., 2000, 44, 7178. 